Bruno Kampmann

\title{
French Makers' Improvements to Brass Instruments in the mid-19th Century, Compared with Those by Adolphe Sax
}

Introduction Adolphe Sax's major inventions are well known, and were far superior to those of his contemporaries in France. However, many Sax patents have today been forgotten, while the patents of certain French instrument makers proved important in the history of the improvement of brass instruments. Certain innovations by Sax had also been invented in part and patented by people before him, and some of these devices are now widely used.

This paper deals with several important improvements to brass instruments that originated with French makers, and we shall here compare them with those of Adolphe Sax in order to determine what was really new about Sax's ideas.

General context During the I $^{\text {th }}$ century, the invention of pistons and valves completely changed the design of brass instruments. They became fully chromatic, and the crooks and shanks slowly and progressively disappeared because they were no longer necessary. The numerous universal exhibitions held in Western Europe were major world events, and each instrument maker endeavoured to present new models and inventions at every such occasion. This stimulated research in general, and all makers were keen to invent extraordinary devices to help them win medals and be recognised as prominent in their field. New improvements could concern:

- the kind of valves,

- valve combinations,

- the instruments' bore and shape,

- the mouthpiece,

- or additional useful devices.

Labbaye On 7 December 1826, Jacques-Michel Labbaye patented a trompette d'harmonie à ventilateur et à piston (Figures I and 2). This trumpet had the standard shape, with three Stoelzel valves in the standard descending pattern (respectively one tone, a semitone, and one-and-a-half tones below the fundamental). It was one of the first patents for a valve instrument in France. Up until I840, many cornets were built with only two valves. However, this trumpet had no tuning slides. Labbaye wrote:

"The drawings attached to my request only correspond to trumpets with three valves: their number can be augmented by two more. I propose to equip French horns with the same mechanism as the one described above. My rights must then be extended to that latter instrument, as they are to the 
perfected trumpet. [...] My new trumpets are liable to be built with a variety of shapes; but the shape that seems preferable to me is that of figure $\mathrm{r}$ : it is much easier to handle, and the sound that comes out of the bell is freer and more powerful. As the case may be, I shall build those in all shapes, and the amateurs who like those sorts of instruments will ultimately judge for themselves."

"Les dessins qui accompagnent ma demande ne représentent que des trompettes à trois ventilateurs: ce nombre peut être augmenté de deux autres. Je me propose d'établir des Cors d'harmonie auxquels j'adapterai le même mécanisme que celui-ci-dessus décrit. Mon droit privatif doit donc s'étendre à ce dernier instrument, comme à la trompette perfectionnée. [...] Mes nouvelles trompettes sont susceptibles de recevoir toutes espèces de formes; mais celle qui me parait devoir être préférée, est représentée par la fig. Ière: elle est beaucoup plus commode à manier, \& le son qui sort par le pavillon, est plus libre \& plus sonore. Du reste, j'en établirai de toutes les formes, \& les amateurs de ces sortes d'instruments jugeront en dernier ressort."

Patents for brass instruments began being filed in France long before Sax. The three-valve arrangement, the general shape, different variations in the shape, and applying these to several families of instruments - nearly all these important matters had already been invented.

Jahn On I9 October I835, Frédéric Jahn patented a trombonne a pistons (Figure 3), which was probably the first-ever mention of this instrument. The patent states:

"He is gratified to state that the trombone comes in three types, in other words there exist a bass trombone, an alto trombone and a tenor trombone. But they are all still the same model, the only difference residing in the size and volume of the instrument".

"Il a l'honneur de faire observer que le trombonne possède trois dénominations, c'est-à-dire qu'il existe trombonne basse, trombonne alto et trombonne ténor, et cependant c'est toujours le même modèle, qu'il n'y a de différence que dans le volume de l'instrument qui est plus ou moins grand". ${ }^{2}$

This valve trombone has the same shape as the slide trombone, and the bore is close to that of the "clavicor" patented by Guichard that same year. This patent is clearly made for a complete family of instruments, so Sax was not the first maker to patent a complete family of instruments with the same pattern!

Couturier On I3 October I852, Jacques Couturier patented an ophicléide à cplindre ou à piston (Patent 14657, Figure 4). He stated the following:

"The key system of the present-day ophicleide counts ten keys placed on the bell and one on a branch. The tone of the last four keys is always very muted, because the air flows through a narrow tube. To

1 Brevet d'invention Jacques-Michel Labbaye (I826), Institut national de la propriété industrielle, Paris [INPI], IBA2532, pp.4f. (all English translations by the author). All patents cited may be found online: http://bases-brevetsıge.inpi.fr (26 June 2018).

2 Brevet d'invention Frédéric Jahn (I835), INPI, IBA5I89, p.3. 
make it louder and cleaner, I got rid of them and replaced them with a piston or rotary valve that demands a new fingering that is simpler and easier to play than the previous instrument."

"Le jeu de l'Ophicléide actuel se compose de dix clefs qui sont placées sur le pavillon et sur une branche. Le son des quatre dernières clefs qui passe par un tube étroit est toujours très sourd. Pour le rendre plus fort et plus net, je les ai supprimées en les remplaçant par un piston ou cylindre à rotation qui a exigé un nouveau doigté dont le jeu est plus simple et plus facile que dans l'ancien instrument."3

However, when the valve is used in combination with the keys, the ophicleide is out of tune.

Adolphe Sax later also patented saxhorns with valves and keys that have the same problems. In this case, his purpose was not to replace keys with valves, but to add keys to a standard saxhorn to enable it to play trills and ornaments.

Halary On 9 August I855, Jules-Léon Anthoine patented the pavillons à coupe parabolique applicables aux instruments de musique (Patent 244I9; he is named Jules-Léon Halary in this patent). He explained:

"In our military bands, and mainly in cavalry ones, instruments with vertical bells (called upright bells) are used. That shape is clearly adverse to the transmission of sound, as it is thrown towards the higher regions where the air is more rarefied and consequently less able to conduct sounds. Without modifying the shape of the body of the instrument, my new bell preserves all the sonorousness, brightness and ease of the instrument, and thus stands as a faithful reproduction of the human throat and larynx."

"Dans nos musiques militaires et principalement celles de cavalerie, on se sert d'instruments à pavillons verticaux dits pavillons en l'air. Cette forme est tout-à-fait contraire à la transmission du son, puisqu'il est lancé dans les couches supérieures de l'air plus raréfiées et par conséquent moins conductrices du son. Mon nouveau pavillon sans modifier la forme du corps de l'instrument, lui fait rendre toute sa sonorité, tout son éclat et toute sa facilité, il est la reproduction fidèle du Gosier ou Larynx humain."4

Note his scientific explanation of this kind of bell: the upper levels of the air are more rarefied, he claims, and in consequence the sound is less powerful. This might be true if we were talking about several miles in altitude, but not the couple of feet involved here.

Sax patented the same parabolic bell in I859, but instead of a fixed position, it has a pivoting bell.

Guichard On 29 December I835, just I5 years after Halary's ophicleide patent, JeanAuguste Guichard patented his ophicleide à pistons (Figure 5). It is pitched in $\mathrm{E} b$ (equivalent to an alto or quinticlave), with crooks for $\mathrm{C}$ and $\mathrm{B}$. The bore is rather big and conical, but

3 Brevet d'invention Jacques Couturier (I852), INPI, IBBI4657, p. 2.

4 Brevet d'invention Jules-Léon Halary (I855), IN PI, IBB244I9, p. 2. 

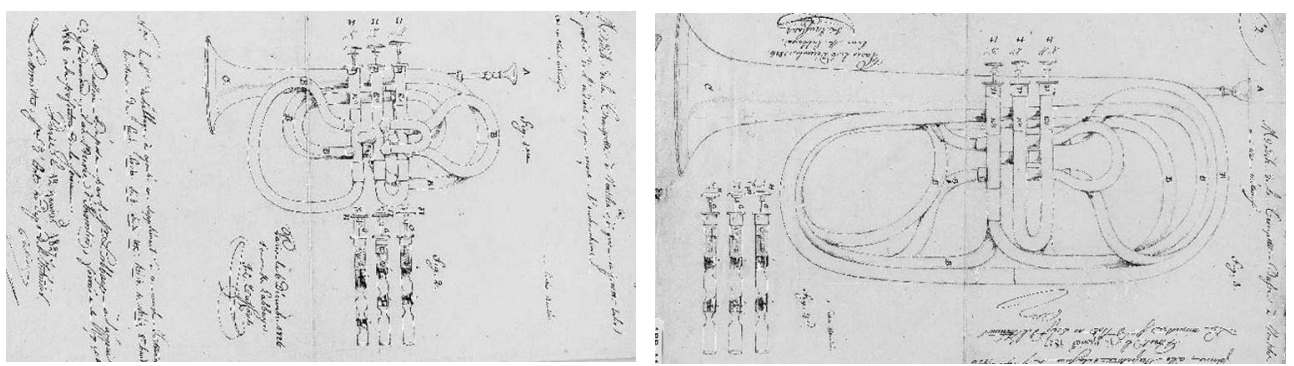

FIGURES I AND 2 Facsimile of Labbaye's patent from 1826.

Source: Institut National de la Propriété Industrielle, IN PI

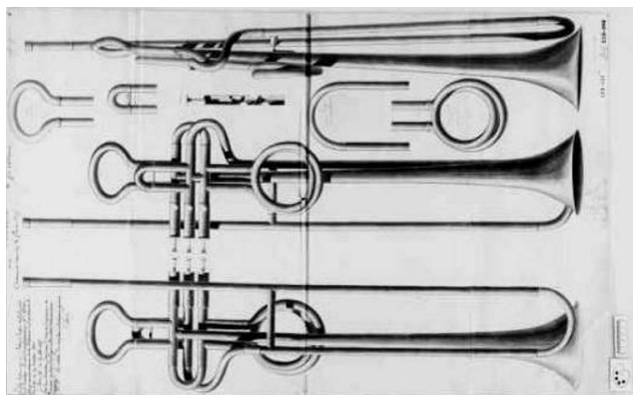

FIGURE 3 Facsimile of Jahn's patent from 1835. Source: INPI

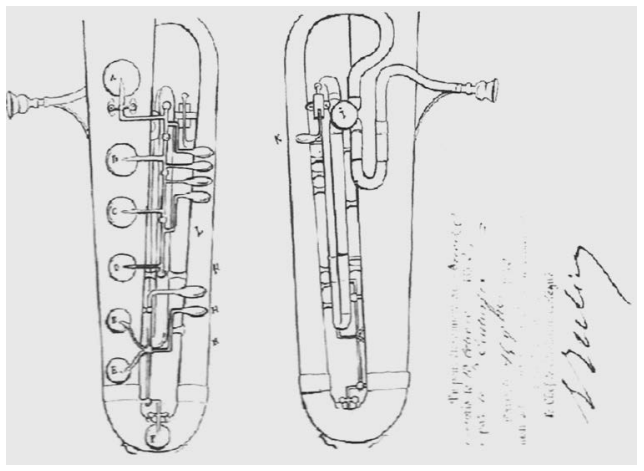

FIGURE 4 Facsimile of Couturier's patent from 1852. Source: INPI

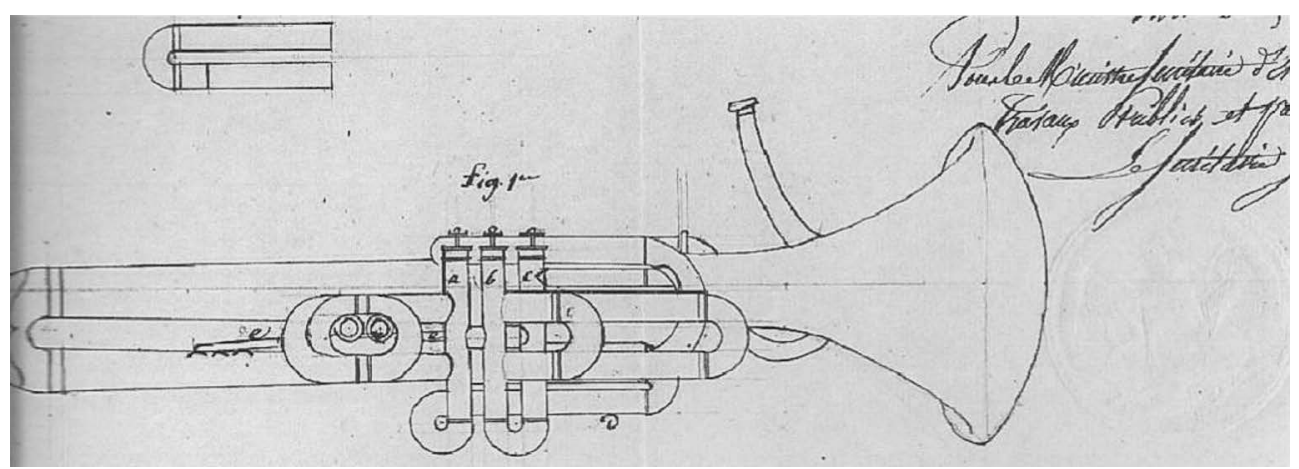

FIGURE 5 Facsimile of Guichard's patent from 1835. Source: IN PI

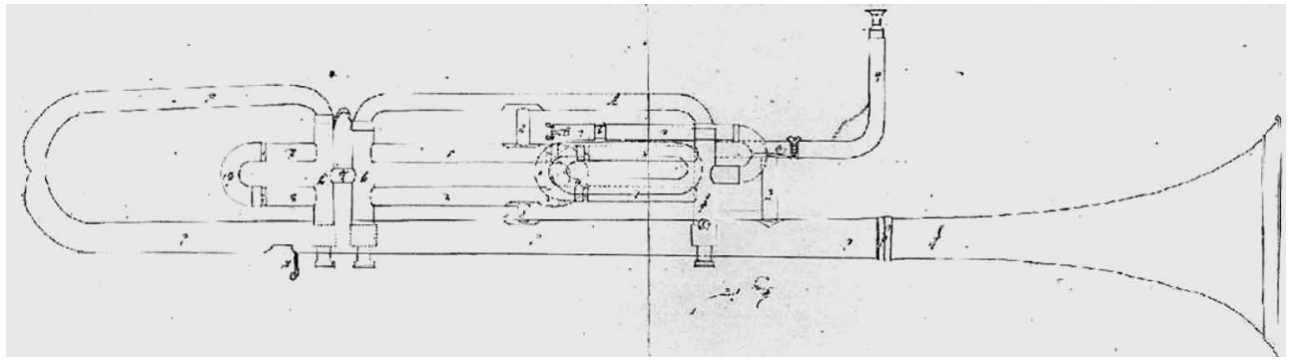

FIGURE 6 Facsimile of Guichard's patent from 1838. Source: IN PI 
the tube length is twice that of the keyed ophicleide. If you replace the Stoelzel valves with Berlin valves, then this instrument is not very different from a saxhorn.

On 22 May I838, Jean-Auguste Guichard patented his clavicor (Figure 6). It is pitched in $\mathrm{E} b$ (equivalent to an alto or quinticlave), with crooks for $\mathrm{C}$ and B. He says: "instrument en cuivre nommé Clavicor, et pouvant remplacer avec avantage l'ophicléide-alto". ${ }^{5}$

The bore is rather narrow and cylindrical. If you replace the Stoelzel valves with Berlin valves, then this instrument is not very different from a saxotromba.

Gautrot Gautrot was the most important manufacturer in the second half of the $19^{\text {th }}$ century, offering cheap instruments, pacotille, as well as high-quality ones. He was frequently involved in lawsuits with Sax, and offered saxhorns identical to his. Gautrot was a businessman, not an inventor, but his firm patented many brass improvements, with each patent and its appendices containing several different inventions. It is not the purpose of this paper to describe them all in detail, ${ }^{6}$ but the following table lists the main inventions for each patent: ${ }^{7}$

\begin{tabular}{|c|c|c|}
\hline $\mathrm{N}^{\circ}$ patent & Date & Nature of the invention \\
\hline \multirow[t]{4}{*}{5874} & oI/07/1847 & Omnitonic horn with 3 rotary valves and I slide \\
\hline & 20/09/1847 & Omnitonic cornet with I rotary valve and I slide \\
\hline & II/O2/I848 & \\
\hline & $06 / 05 / 1851$ & \\
\hline $62 I I$ & 2I/o8/I847 & Perfections on the ophicleide \\
\hline \multirow[t]{4}{*}{ I 3732} & $27 / 05 / 1852$ & Water key for slide trombone ("syphon”) \\
\hline & & Rubber joint for pistons \\
\hline & $\mathrm{OI} / \mathrm{I} 2 / \mathrm{I} 852$ & Rotary valve moved by piston \\
\hline & I7/OI/I853 & Rotary valve moved by piston (improvement) \\
\hline \multirow[t]{4}{*}{20292} & 22/07/1854 & Omnitonic horn (rotary valve with io tubes) \\
\hline & & Clock spring for rotary valves or ophicleide keys \\
\hline & & Omnitonic cornet (rotary valve with 8 tubes) \\
\hline & & Automatic tuning of slides \\
\hline
\end{tabular}

5 "[A] brass instrument called Clavicor, which can replace the alto ophicleide advantageously". Brevet d'invention Jean-Auguste Guichard (I838), INPI, IBA6768, p. I.

6 For more information on Gautrot see for example Cyrille Grenot's article on "La facture instrumentale des cuivres dans la seconde moitié du xix ${ }^{\mathrm{e}}$ siècle en France" and Claude Maury's on "Les cors omnitoniques", in: Romantic Brass. Französische Hornpraxis und historisch informierter Blechblasinstrumentenbau. Symposium 2, ed. by Daniel Allenbach, Adrian von Steiger and Martin Skamletz, Schliengen 2016 (Musikforschung der Hochschule der Künste Bern, Vol.6), pp. II-IO2 and I03-I53.

7 This list only contents the wind instrument patents - some more were granted to Gautrot on timpani and percussions, see http://bases-brevetsige.inpi.fr/. 


\begin{tabular}{|c|c|c|}
\hline & & Pistons with reduced course \\
\hline & & Pistons moving in a spiral \\
\hline & & Pistons with smooth angles \\
\hline & 22/I2/I854 & Ophicleide transposing in 2 different keys \\
\hline & I5/OI/I855 & Omnitonic horn (rotary valve with 8 tubes) \\
\hline & $05 / 06 / 1857$ & Tap replacing additional crook \\
\hline 28000 & $04 / 06 / 1856$ & Conical bore (all kind of valves) \\
\hline & I9/09/1856 & Piston without screw \\
\hline & & New design for rotary valve \\
\hline & $06 / 07 / 1857$ & Conical bore (extension to all families) \\
\hline & 30/10/1857 & Stoelzel valves without air at the bottom (toric shells) \\
\hline & $08 / 04 / 1858$ & Stoelzel valves with shortened air column in the valve \\
\hline & $28 / 07 / 1858$ & Device for introducing clock springs into cases easily \\
\hline & $09 / 09 / 1858$ & Circular design for brasswind families \\
\hline & $22 / 12 / 1858$ & 2 Stoelzel valves without air at the bottom and I Périnet valve between them \\
\hline & & Compensating valve ("piston à double effet") for duplex instruments \\
\hline & $27 / 01 / 1862$ & Compensating valve ("piston à double effet") for double horn \\
\hline & & Transposing valve ("piston transpositeur") \\
\hline $46 I I 7$ & $28 / 07 / 1860$ & Stoelzel valves without air at the bottom, improvements, light shells \\
\hline & $25 / 08 / 1860$ & Stapled, curved, additional tubes for valves \\
\hline 56450 & $22 / \mathrm{II} / 1862^{8}$ & New design for saxhorns with bell and mouthpipe on opposite sides \\
\hline 65313 & OI/I2/I864 & Compensating valve ("equitonique") for 5 valves (3 rows of additional tubing) \\
\hline & $05 / 07 / 1865$ & Compensating valve ("equitonique"), new applications \\
\hline & $25 / 10 / 1865$ & $\begin{array}{l}\text { Compensating valve ("equitonique"), application to instruments playing } \\
\text { in } 2 \text { pitches }\end{array}$ \\
\hline
\end{tabular}

Some of these inventions are really useful and still in use today. For example, there are the spphon, an automatic water key for slide trombone (Figure 7), and the spstème équitonique (Figure 8), the first efficient compensating system, patented a long time before the Blaikley system to which it is identical. By contrast, Sax's patents for brasswind instruments were generally not a success. Only his saxhorn/saxotromba family was widely used, but there was nothing really new about that invention.

Thibouville-Lamy Jérôme Thibouville-Lamy patented a clé corrective on 8 August I874 (No. I04550, Figure 9). One or two keys on the saxhorn bell, used either open or closed, help to correct the pitch of valve combinations. However, the valve combinations are too high, and it is more useful to lower the note than to elevate it. It has the same idea as Sax's invention of saxhorns with valves and keys.

8 A "certificat d'addition" to this patent was added on II September I863. 
FIGURE 7 Facsimile of Gautrot's patent from 1852 . Source: IN PI
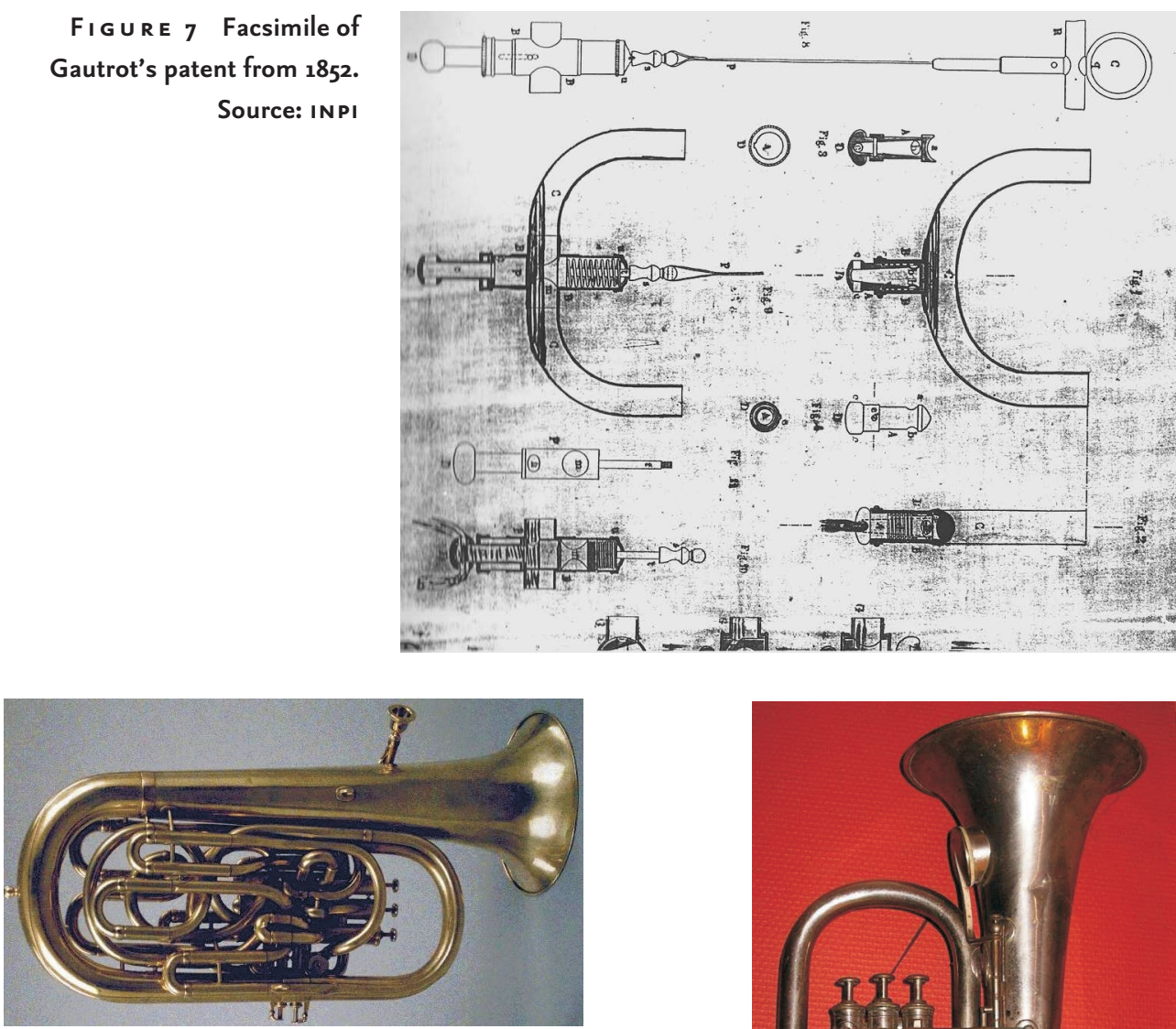

FIGURE 8 A Gautrot saxhorn equitonique with 3 rows of tubing. Source: Musée de la Musique, Paris; photo: Thierry Ollivier

FIGURE 9 A Thibouville saxhorn with one corrective key. Source: Collection Camboulive

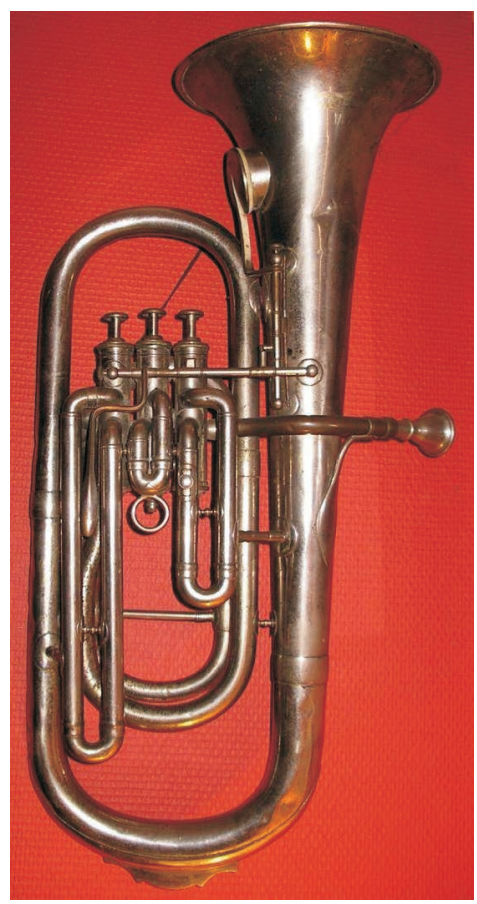

Cousin On I7 February I873, Jean Léon Cousin patented the instruments à cinq pistons (5-valve brasswinds, Figure Io). The aim is the same as Sax's, namely to avoid combinations of valves. However, the use of dependent, standard Perinet valves allows one to keep the same fingering for the first three valves, avoiding the task of learning a new fingering. The number of semitones lowered is 2, I, 3, 5 and 4 in succession. This idea is still used on French saxhorns with five valves. 


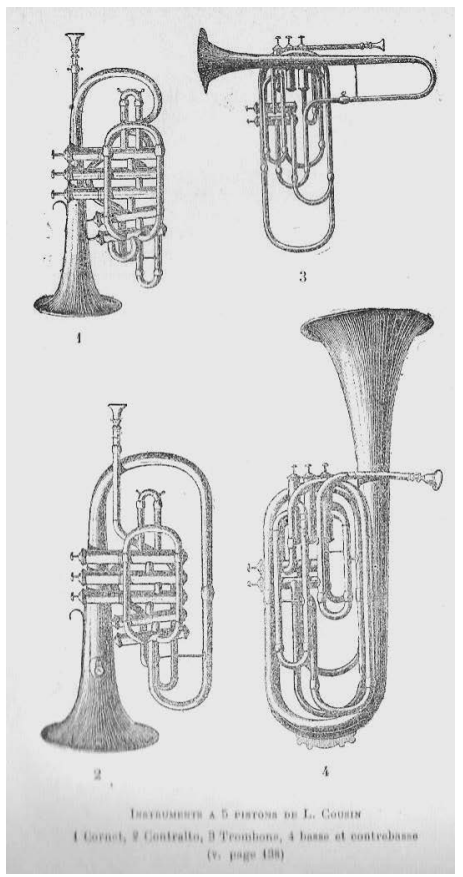

FIGURE 10 Constant Pierre: La facture instrumentale à l'exposition universelle de 1889, Paris 189o, p. 139

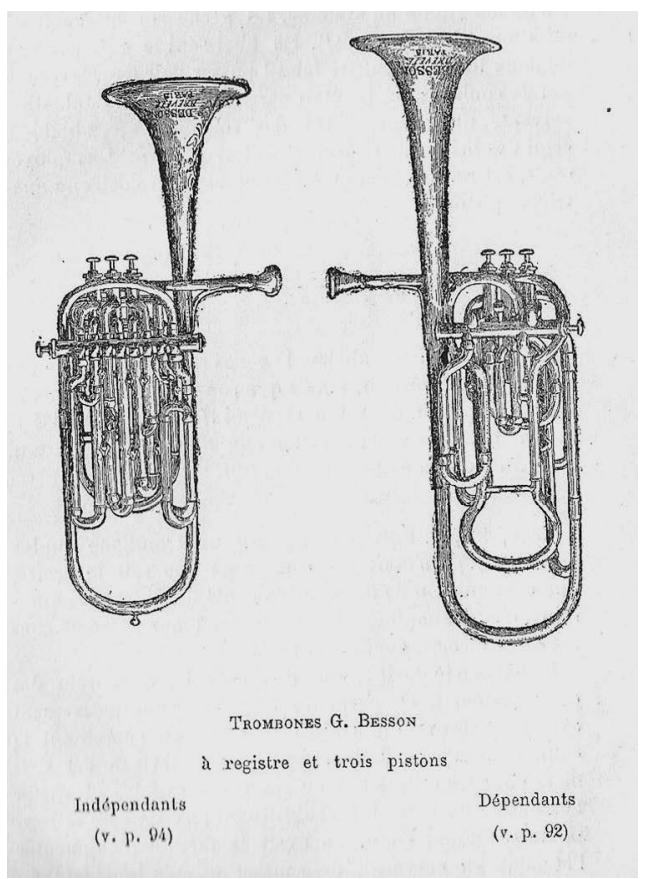

FIGURE 11 Pierre: La facture instrumentale, p.93

Besson After Sax's invention of the trombone with independent valves, Besson proposed his registre, which was adapted to valve slides to obtain new notes (Figure II). The fourth valve registre lowers the pitch by 2 tones. It crosses the valve slides of the other valves to add a new length in combination with these valves. The same idea would later be used for horns by Wunderlich, where 24 tubes are connected to the register.

Conclusion After a detailed survey of French patents registered by different makers for brass instruments, it is clear that Sax's ideas were not completely new, for the same device was also patented by other French makers, in some cases before Sax.

Sax's main invention is the saxhorn/saxotromba, which is not so different from the ophicléide à pistons, but was built as a complete family of instruments with the same bore proportions and fingerings, and using a Berlin valve instead of the Stoelzel valve.

For brasswind instruments, Sax's legacy is primarily that he rationalised existing ideas and built high-quality instruments, rather than having invented anything really new, as he did with the saxophone. 


\section{Inhalt}

Vorwort 7

Adrian von Steiger "Agilité, homogénéité et beauté". The Saxhorn in the Context of the Opéra and Military Music 9

Eugenia Mitroulia/Arnold Myers The Saxhorn Families I8

Malou Haine Une nouvelle source d'archives pour identifier les marques de fabrique de facteurs d'instruments de musique (I860 à I9I9)

Stewart Carter Kastner, the Distin Family, and the Emergence of the "New" Brasswind Instruments by Adolphe Sax 68

Sabine K. Klaus Wieprecht versus Sax. German Roots of Adolphe Sax's Brasswind Designs 97

Ignace De Keyser The Construction of the Genius in

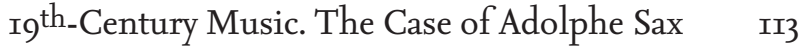

Cyrille Grenot Deux faillites d'Adolphe Sax, I873 et I877. Présentation et documents $\quad$ I46

Reimar Walthert The First Twenty Years of Saxhorn Tutors $\quad 155$

Bruno Kampmann French Makers' Improvements on Brass Instruments in the mid-I th $^{\text {th }}$ Century, Compared with Those by Adolphe Sax $\quad$ I68

Jeroen Billiet Adolphe Sax's Ultimate Masterpiece. The History, Design and Use of the Cor Sax à six pistons indépendants $\quad$ I76

Daniel Allenbach „Une réforme tellement logique« oder »à classer au rang des utopies«? Henri Chaussiers »instruments en Ut« $\quad$ I88

Gregor Widholm Das Wiener Horn - ein Instrument des I9. Jahrhunderts als erste Wahl in Orchestern des 2I. Jahrhunderts 223

Martin Skamletz »... und gar nichts, wodurch sich der eigene schöpferische Geist des Komponisten beurkundete«. Cherubini, Hummel, Konzerte, Opern, Quodlibetes und Trompeten in Wien zu Beginn des I9. Jahrhunderts.

Teil 3 und Schluss: Anton Weidinger und sein Instrument 245

Rainer Egger/Martin Mürner $\quad$ Restaurierungsergebnisse messbar machen $\quad 262$ Namen-, Werk- und Ortsregister 272

Die Autorinnen und Autoren der Beiträge $\quad 283$ 


\section{DAS SAXHORN}

Adolphe Sax' Blechblasinstrumente im Kontext ihrer

Zeit. Romantic Brass Symposium 3 - Herausgegeben von Adrian von Steiger, Daniel Allenbach und Martin Skamletz 


\section{MUSIKFORSCHUNG DER Hochschule der KÜnste Bern Herausgegeben von Martin Skamletz und Thomas Gartmann}

Band 13 
2 Dieses Buch ist in gedruckter Form im April 2020 in erster Auflage in der Edition Argus in Schliengen/Markgräflerland erschienen. Gestaltet und gesetzt wurde es im Verlag aus der Seria und der SeriaSans, die von Martin Majoor im Jahre 2000 gezeichnet wurden. Gedruckt wurde es auf Eos, einem holzfreien, säurefreien, chlorfreien und alterungsbeständigen Werkdruckpapier der Papierfabrik Salzer im niederösterreichischen Sankt Pölten. Das Vorsatzpapier Caribic cherry wurde von Igepa in Hambug geliefert. Rives Tradition, ein Recyclingpapier mit leichter Filznarbung, das für den Bezug des Umschlags verwendet wurde, stellt die Papierfabrik Arjo Wiggins in Issy-les-Moulineaux bei Paris her. Das Kapitalband mit rot-schwarzer Raupe lieferte die Firma Dr. Günther Kast aus Sonthofen im Oberallgäu, die auf technische Gewebe und Spezialfasererzeugnisse spezialisiert ist. Gedruckt und gebunden wurde das Buch von der Firma Bookstation im bayerischen Anzing. Im Internet finden Sie Informationen über das gesamte Verlagsprogramm unter www.editionargus.de, zum Institut Interpretation der Hochschule der Künste Bern unter www.hkb.bfh.ch/interpretation und www.hkb-interpretation.ch. Die Deutsche Nationalbibliothek verzeichnet diese Publikation in der Deutschen Nationalbibliografie; detaillierte bibliografische Daten sind im Internet über www.dnb.de abrufbar. (C) der zeitgleich erschienenen digitalen Version: die Autorinnen und Autoren, 2020. Dieses Werk ist lizenziert unter einer Creative Commons Namensnennung-Nicht kommerziell 4.0 International Lizenz (CC BY-NC 4.o). DOI: https://doi.org/I0.26045/kp64-6I77 ISBN 978-3-93I264-93-2 